\title{
Antibiotics to Prevent Relapse of Adjustable Gastric Balloon Hyperinflation: Feasible for Balloon Maintenance?
}

\author{
Eduardo Usuy ${ }^{a}$ Marco Silvab Manoel dos Passos Galvão Neto ${ }^{c}$ \\ Eduardo Greccoc $^{c}$ Thiago Ferreira de Souzac ${ }^{c}$ Luiz Gustavo de Quadros ${ }^{c}$ \\ ${ }^{a}$ Usuy Clínica Médica, Florianópolis, Brazil; ${ }^{\text {b}}$ Gastroenterology Department, Centro Hospitalar de São João, \\ Porto Medical School, Porto, Portugal; ' ABC Medical School, São Paulo, Brazil
}

Keywords

Bariatric endoscopy · Intragastric balloon · Hyperinflation

\section{Abstract}

The placement of an intragastric balloon (IGB) plays an increasingly important role in the treatment of obesity. The authors describe the cases of 2 female patients, 34 and 62 years old, who were submitted to the implantation of a Spatz ${ }^{\circledR}$ IGB to treat obesity. Ten to fourteen weeks later, the patients presented complaints of epigastric pain, vomiting, and abdominal distension. A bulging of the upper abdominal wall was noticed upon physical examination. Upper gastrointestinal endoscopy confirmed the clinical suspicion of IGB hyperinflation. It was decided to remove the $500 \mathrm{~mL}$ of saline solution with methylene blue from inside the balloon. During the same procedure, the IGB was refilled with $500 \mathrm{~mL}$ offresh saline solution, methylene blue, and empiric $\beta$-lactam antibiotic. The extracted content of the hyperinflated IGB was sent for microbiological culturing and was found to be positive for Streptococcus viridans in one of the cases. In the other case, the culture examination was negative, and after 8 weeks, the patient presented again with hyperinflation of the IGB. It was then decided to substitute the IGB with another balloon; the procedure was uneventful. The content of the removed IGB was sent for microbiological testing, and colonization by Candida tropicalis was confirmed. This is a rare but potentially serious complication of IGB placement. Randomized trials are needed to clarify the role of antibiotics and antifungals in primary and secondary prophylaxis against IGB hyperinflation.

(C) 2020 Sociedade Portuguesa de Gastrenterologia Published by S. Karger AG, Basel

\section{Antibióticos para prevenir recidiva da hiperinsuflação de balão intragástrico ajustável: é possível manter o balão?}

Palavras Chave

Endoscopia bariátrica • Balão intragástrico · Hiperinsuflação

\section{Resumo}

A colocação de um balão intragástrico (BIG) desempenha um papel cada vez mais importante no tratamento da obesidade. Os autores descrevem os casos de duas doentes, com 34 e 62 anos de idade, que colocaram BIG Spatz ${ }^{\circledR}$ para tratamento da obesidade. Dez a catorze semanas após as doentes apresentaram queixas de dor epigástrica,

Eduardo Usuy and Marco Silva contributed equally to this work. karger@karger.com www.karger.com/pjg

(c) 2020 Sociedade Portuguesa de Gastrenterologia Published by S. Karger AG, Basel

\section{Karger'?}

BOPEN ACCESS
This article is licensed under the Creative Commons AttributionNonCommercial-NoDerivatives 4.0 International License (CC BYNC-ND) (http://www.karger.com/Services/OpenAccessLicense). Usage and distribution for commercial purposes as well as any distribution of modified material requires written permission.
Marco Silva

Gastroenterology Department, Centro Hospitalar de São João Porto Medical School, Alameda Professor Hernâni Monteiro PT-4200-319 Porto (Portugal)

marcocostasilva87@gmail.com 
vómitos e distensão abdominal. Um abaulamento da parede abdominal superior era evidente no exame físico. A endoscopia digestiva alta confirmou a suspeita clínica de hiperinsuflação do BIG. Decidiu-se remover os $500 \mathrm{~mL}$ de solução salina com azul de metileno do balão. Durante o mesmo procedimento, o BIG foi preenchido com 500 $\mathrm{mL}$ de nova solução salina, azul de metileno e antibiótico $\beta$-lactâmico empírico. O conteúdo extraído do BIG hiperinsuflado foi enviado para cultura microbiológica que foi positiva para Streptococcus viridans em um dos casos. No outro caso, o exame de cultura foi negativo e após oito semanas, a doente apresentou novamente hiperinsuflação do balão. Foi então decidido substituir o balão; o procedimento decorreu sem intercorrências. O conteúdo do BIG removido foi enviado para exames microbiológicos, tendo sido identificada colonização por Candida tropicalis. Esta é uma complicação rara, mas potencialmente grave, da colocação do BIG. Ensaios clínicos randomizados são necessários para esclarecer o papel dos antibióticos e antifúngicos na profilaxia primária e secundária contra a hiperinsuflação do BIG.

(C) 2020 Sociedade Portuguesa de Gastrenterologia Publicado por S. Karger AG, Basel

\section{Introduction}

Obesity is a chronic disease whose prevalence has increased worldwide, causing an increase in burden on the individual and for healthcare systems [1]. The treatment of obesity requires a multidisciplinary evaluation, with nutritional guidance and lifestyle changes, including adequate physical exercise. However, these measures alone do not generally provide satisfactory and long-lasting results. Bariatric surgery is well established to treat patients with a BMI of $>40$ or a BMI $>35$ when they have comorbidities; this is still the most effective long-term option [2]. However, in cases of Class I or II obesity without comorbidities, the best modality of treatment remains uncertain [2].

Endoscopic techniques play an increasingly important role in the treatment of obesity, especially in cases of Class I and II obesity, when the patient refuses surgery and in the treatment of complications resulting from bariatric surgeries. The placement of an intragastric balloon (IGB) is the most commonly performed endoscopic procedure, as it is a minimally invasive option to treat obesity [3].

Herein we report a rare but potentially serious complication of IGB placement.

Prevention of Adjustable Gastric Balloon Hyperinflation

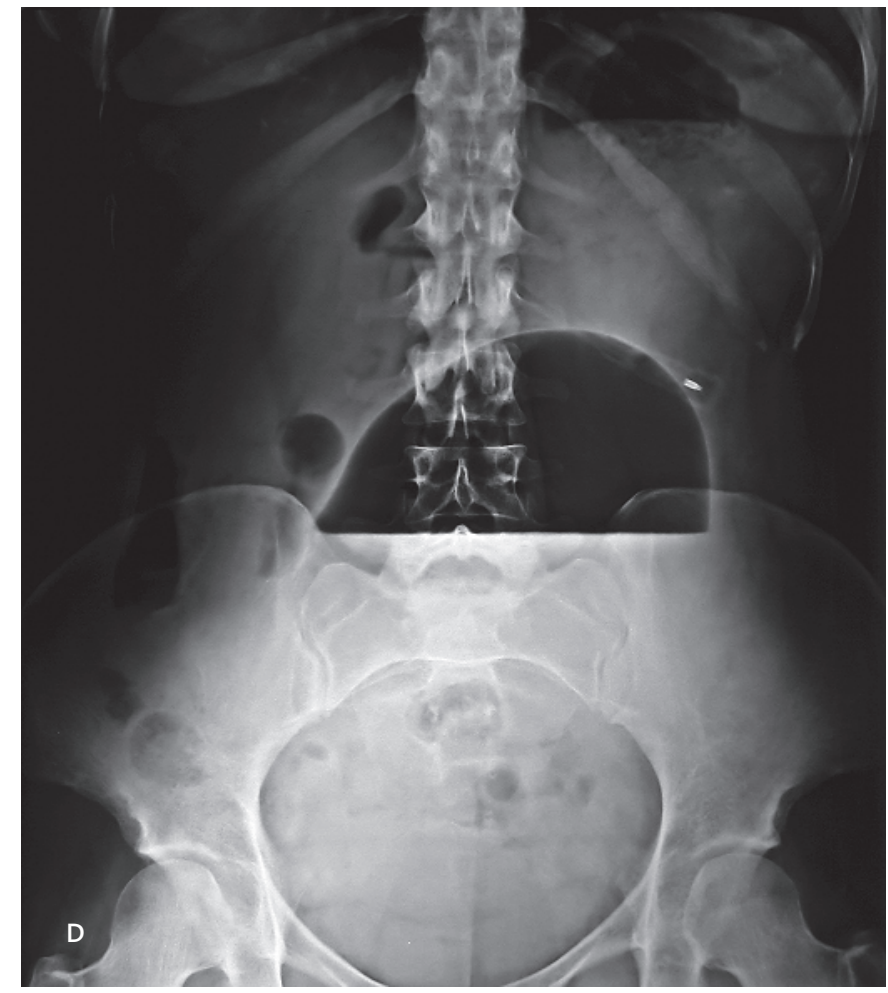

Fig. 1. Abdominal X-ray showing an enlarged intragastric balloon with a clear indication of the air-fluid level.

\section{Case Report and Case Presentation}

Case 1

This is the case of a 62-year-old female with a BMI of 30 (body weight: $70.5 \mathrm{~kg}$ ), who was submitted to the implantation of a Spatz3 ${ }^{\circledR}$ IGB (Spatz Medical, Great Neck, NY, USA) to treat obesity. The patient had no other comorbidities. Fourteen weeks after placement of the IGB, the patient returned to the bariatric endoscopy service with complaints of epigastric pain, vomiting, and abdominal distension. Upon physical examination, the patient presented a bulging of the upper abdominal wall, with discomfort on light palpation but with no other signs of peritoneal irritation or hemodynamic instability. Abdominal X-ray showed a grossly distended IGB with an air-fluid level.

Upper gastrointestinal endoscopy was performed under general anesthesia and orotracheal intubation, which confirmed the clinical suspicion of IGB hyperinflation. It was decided to remove the $500 \mathrm{~mL}$ of saline solution with methylene blue from inside the balloon. During the same procedure, the IGB was refilled with 500 $\mathrm{mL}$ of fresh saline solution, methylene blue, and empiric amoxicillin in an attempt to prevent IGB hyperinflation recurrence (Fig. 1). The extracted content was sent for microbiological culturing and was found to be positive for Streptococcus viridans (sensitive for penicillin, cephalosporins, and macrolides) and negative for fungi. The patient presented a good evolution with removal of the IGB 3 months later without further complications. At the time of removal, the patient weighed $60 \mathrm{~kg}$ (total body weight loss of $10.5 \mathrm{~kg}$ in 12 months). 
Fig. 2. a Endoscopic image showing significant air-fluid levels (on the right, liquid of the intragastric balloon placement, and on the left, air). b Endoscopic image after the IGB was refilled with fresh saline solution and antibiotic.
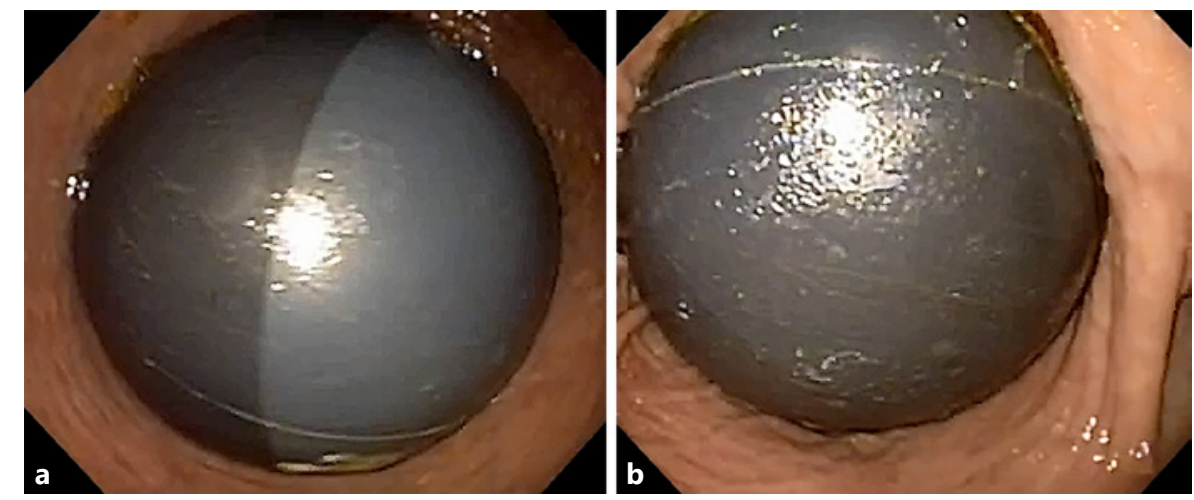

\section{Case 2}

A 34-year-old female with a BMI of 28(body weight: $69.7 \mathrm{~kg}$ ) with no comorbidities was submitted to the placement of a Spatz3 IGB to treat excessive weight. Ten weeks after the procedure, the patient started complaining about epigastric discomfort, food intolerance, and abdominal distension. At physical examination, the patient presented bulging in the epigastric region with no signs of peritoneal irritation or hemodynamic instability.

Due to the suspicion of hyperinflation of the IGB, an upper gastrointestinal endoscopy was performed that confirmed the presence of hyperinflation of the IGB. The contents of the balloon (500 $\mathrm{mL}$ of saline solution with methylene blue) were aspirated and sent to investigate for possible bacterial and fungal contamination (suppl. video; for all supplementary material, see www. karger.com/doi/10.1159/000507226). The IGB was refilled with $500 \mathrm{~mL}$ of fresh saline solution, methylene blue, and ceftriaxone, again as secondary prophylaxis of IGB hyperinflation (Fig. 2). However, the culture examination was negative, and after 8 weeks, the patient again presented with hyperinflation of the IGB. It was then decided to substitute the IGB with another balloon; the procedure was uneventful. The content of the removed IGB was sent for microbiological testing and colonization by Candida tropicalis was confirmed. The second IGB was removed after 8 months, without further complications. The patient presented a total body weight loss of $9.3 \mathrm{~kg}$ in 12 months.

\section{Discussion and Conclusion}

The use of an IGB is a restrictive and temporary but repeatable method of inducing weight loss. It consists of endoscopically placing a soft balloon filled with saline solution or air in the stomach [4]. IGB placement is increasingly becoming an option to treat obesity in patients with BMI $>27$ in Europe or $>30$ in the United States when a patient fails to control weight with diet and exercise, does not fulfil the criteria to undergo bariatric surgery, or refuses surgery [3].

The balloon acts as a space-occupying device, reducing the capacity of the stomach and increasing the early sensa- tion of satiety and, thus, reducing the caloric intake. Another possible mechanism of action that may contribute to weight loss is delaying gastric emptying $[5,6]$. Because its mechanism of weight loss is primarily restrictive, its effectiveness depends on the patient's adherence to lifestyle changes (diet and exercise). On average, this method allows a loss of about $18 \%$ of the total body weight [1].

On the other hand, the placement of an IGB is contraindicated in patients who underwent gastric surgery and those who have potential gastrointestinal tract bleeding, esophageal varices, large hiatal hernia $(>5 \mathrm{~cm})$, or any contraindication to endoscopy $[3,7]$.

There are several models of IGBs that differ in volume, composition, time to removal, and mode of insertion and removal; however, weight loss does not seem to vary significantly between them $[3,8]$. The Spatz adjustable balloon system was introduced in 2010. It is an endoscopically placed saline solution-filled silicone balloon that is approved for 12-month deployment; most other IGBs are only deployed for 6 months [9]. The Spatz balloon features a removable inflation tube that allows volume adjustment as required after insertion [9]. If the patient has food intolerance or pain, some liquid can be removed from the balloon while the balloon remains in the stomach. On the other hand, fluid may be added if the appetite increases or the weight loss reaches a plateau [9].

The most common adverse events associated with IGBs are nausea, vomiting, and mild abdominal pain (up to $33 \%$ of the cases), which may require early removal [10]. Other possible complications include gastric ulcers, spontaneous deflation, rupture, colonization by fungus, balloon migration with intestinal obstruction, esophageal laceration/perforation, and gastric perforation [3, 9]. Recently, the Food and Drugs Administration issued a warning about the possibility of another complication with these balloons - hyperinflation of the balloon re- 
quiring its early removal [10]. Symptoms of IGB hyperinflation include severe abdominal pain, abdominal distension (with or without associated pain), dyspnea, and vomiting [10].

The cause of hyperinflation is unknown. When spontaneous hyperinflation of the IGB occurs, treatment may be conservative in asymptomatic cases; however, the removal of the balloon is necessary in symptomatic cases with immediate substitution or replacement scheduled a few days later [3]. The Spatz balloon has the advantage of allowing complete aspiration of its contents followed by refilling with fresh fluid in the same endoscopic session. In the Brazilian IGB Consensus Statement [3], the prophylactic use of antibiotics or antifungals to avoid hyperinflation is not recommended because there is no scientific evidence that the cause of this adverse event is infectious. However, about 30\% of the participants in these consensuses have the opinion that the use of antibiotic prophylaxis can be performed routinely or in selected cases [3]. In Case 1, the authors opted for the empirical instillation of amoxicillin when refilling the IGB as secondary prophylaxis of IGB hyperinflation with good results despite the growth of a streptococcal species that is not sensitive to this antibiotic, but sensitive to cephalosporins. Thus, based on the experience with this patient, after the diagnosis of hyperinflation of the IGB, prophylactic instillation of ceftriaxone in Case 2 was chosen, but proved unsuccessful.

The authors describe 2 rare cases of acute IGB hyperinflation. This complication should be suspected in cases of vomiting, pain, and abdominal distension after IGB placement. Early recognition and balloon removal may prevent serious complications.

\section{Statement of Ethics}

All rules of the local ethics committee ("Faculdade de Medicina do $A B C$ ”) were followed, preserving patient identity and confidentiality.

\section{Disclosure Statement}

The authors declare that they have no conflicts of interest.

Funding Sources

The authors declare that there was no source of funding.

\section{References}

1 Sullivan S, Edmundowicz SA, Thompson CC. Endoscopic Bariatric and Metabolic Therapies: New and Emerging Technologies. Gastroenterology. 2017 May;152(7):1791-801.

2 Campos JM, Ferreira FC, Teixeira AF, Lima JS, Moon RC, D’Assunção MA, et al. Septotomy and Balloon Dilation to Treat Chronic Leak After Sleeve Gastrectomy: technical Principles. Obes Surg. 2016 Aug;26(8):19923.

3 Neto MG, Silva LB, Grecco E, de Quadros LG, Teixeira A, Souza $\mathrm{T}$, et al. Brazilian Intragastric Balloon Consensus Statement (BIBC): practical guidelines based on experience of over 40,000 cases. Surg Obes Relat Dis. 2018 Feb;14(2):151-9.
4 National Heart, Lung and Blood Institute. Clinical guidelines on the identification, evaluation and treatment of overweight and obesity in adults. The evidence report. Besthesda: National Heart, Lung, and Blood Institute; 1998.

5 Bonazzi P, Petrelli MD, Lorenzini I, Peruzzi E, Nicolai A, Galeazzi R. Gastric emptying and intragastric balloon in obese patients. Eur Rev Med Pharmacol Sci. 2005 Sep-Oct;9(5 Suppl 1):15-21.

$6 \mathrm{Su} \mathrm{HJ}$, Kao CH, Chen WC, Chang TT, Lin CY. Effect of intragastric balloon on gastric emptying time in humans for weight control. Clin Nucl Med. 2013 Nov;38(11):863-8.

7 Dumonceau JM. Evidence-based review of the Bioenterics intragastric balloon for weight loss. Obes Surg. 2008 Dec;18(12):1611-7.
8 De Castro ML, Morales MJ, Del Campo V, Pineda JR, Pena E, Sierra JM, et al. Efficacy, safety, and tolerance of two types of intragastric balloons placed in obese subjects: a double-blind comparative study. Obes Surg. 2010 Dec;20(12):1642-6.

9 Klobucar Majanovic S, Brozovic B, Stimac D. Bariatric endoscopy: current state of the art, emerging technologies, and challenges. Expert Rev Med Devices. 2017 Feb;14(2):14959.

10 de Quadros LG, Dos Passos Galvão Neto M, Grecco E, de Souza TF, Kaiser RL Jr, Campos $\mathrm{JM}$, et al. Intragastric balloon hyperinsufflation as a cause of acute obstructive abdomen. ACG Case Rep J. 2018 Sep;5(1):e69. 